\title{
THE IMPACT OF FARMER PARTICIPATION ON WATER DISTRIBUTION PERFORMANCE IN TWO IRRIGATION SCHEMES IN SRI LANKA
}

\author{
M.M.M. AHEEYAR AND L. E.D. SMITH
}

\section{Introduction}

Irrigation has played a central part in Sri Lanka's cultural heritage, and much has been written about the advanced nature of the ancient irrigation infrastructure and hydraulic civilisation that led to a relatively self sufficient and self reliant economy (Brohier, 1934; Seneviratne 1989). Sri Lanka's economy remains dependent on irrigation for much of its agricultural output, particularly rice (paddy) the main staple, and irrigation based agricultural growth has been the primary development strategy (Barker \& Herdt 1985).

Since independence, investment in the development or rehabilitation of new or existing water resources and irrigation infrastructure, has taken a major share of the development budget. Investment on irrigation development from 1950 to 1985 was, on average, nineteen percent of the total public investment budget per year. Ninety percent of the irrigation investment has been for new construction (Aluwihare \& Kikuchi 1990; IMPSA 1991). ] In addition, the irrigation sub-sector claimed a disproportionate share of the public recurrent budget, arguably hindering the development of rainfed agriculture and other sectors. The development of irrigation has enabled Sri Lanka to achieve ninety two percent self-sufficiency in rice by 1985 (Aluwihare \& Kikuchi 1990), however, the economic returns to specific investment on new construction were often not impressive (Alwis 1986, Chambers 1988).

The situation led to the under performance of Public Irrigation Systems. The research findings suggest that the major causal factors for the under performance included inefficient main system management, neglected maintenance and farmers remaining peripheral to the management systems ${ }^{1}$ (Carruthers \& Morrison, 1994). 
This combination of fiscal constraints and poor technical and economic performance, led planners to re-think policies and introduce reforms. As a result from the early 1980s emphasis was shifted from supply augmentation to system improvement, and from paddy mono- cropping to crop diversification. From 1981-83 attempts were made to implement a previously legislated land tax for irrigated areas, however, collections were minimal (Silva 1986). In 1984, a fee for system operation and maintenance to be paid by water users was introduced, but the collection rate achieved fell rapidly, from eightyfive percent of the amount due in 1984 to less than ten percent in 1985 . Factors contributing to this failure include revenue collection by a centralised agency not linked to improved services, a uniform fee regardless of water availability and scheme conditions, and civil unrest combined with legal challenges to the fee by some farmers. Further, farmers had equal right of access to land and water, irrespective of the payment of the fee.

\section{Quality of Water Distribution Performance During Post independence}

Inefficiency in water use has been identified as a major cause of under performance of irrigation systems by a number of researchers. Moore (1981) observed that the standard of irrigation efficiency on large scale irrigation schemes in Sri Lanka was very low. Deliveries were unpredictable in terms of timing and quantity, and very inequitable between different farmers. In the Minipe scheme, for example, it was found that head-end farmers were still receiving and draining off water after fulfilling their requirement, while tail-enders lack adequate supply (Wickramasekara 1981). The standard of irrigation management in Sri Lanka was judged as among the worst in the world (Chambers 1988).

\section{Farmer Participation in Irrigation Management}

The Government of Sri Lanka made various efforts to solicit farmer participation in irrigation management under various pilot projects and different models. The Integrated Management of Major Irrigation Schemes (INMAS) programme is one such effort which commenced in 
1984. INMAS established a model for participatory irrigation management in thirty seven large irrigation schemes. This model became the basis for the national Participatory Irrigation System Management Policy (PISMP), adopted in 1988. Under this policy, full responsibility for resource mobilisation and management from Distributory Canal (DC) to Field Channel (FC) level of the major irrigation systems, was handed over to farmer organisations [(FOs); FOs are also called Distributory Canal Organizations (DCOs)]. In return, farmers were exempted from payment of the irrigation service fee. The government retained responsibility for operation and maintenance (O\&M) of the head works and main systems.

\section{Participatory Irrigation System Management Model}

The model adopted for the Participatory Irrigation Management consists of a number of organizations at various levels in a scheme (Figure 1). The lowest level of FO is the informal Field Channel Group (FCG). Each FCG has an elected farmer representative (FR) whose major function is to solve problems at the $\mathrm{FC} \mathrm{level} \mathrm{and} \mathrm{bring} \mathrm{issues} \mathrm{to}$ the attention of higher levels.

The next level of FO is the Distributory Canal Organization (DCO). The membership of the DCO comprises all the legal farmers of the distributory canal command area. Office bearers for the DCOs are selected from farmer representatives selected by the FCGs. The DCO is responsible for water distribution among $\mathrm{FCs}, \mathrm{O} \& \mathrm{M}$ of the DCs, resolving disputes not solved by the $\mathrm{FCs}$ and other needed activities.

Each irrigation scheme has a Project Management Committee (PMC) which consists of selected FRs from the DCOs and scheme level officers from the line agencies. The PMC is the venue for joint management of the system at scheme level. It has the responsibility to prepare the seasonal agricultural plan, co-ordinate efforts among agencies, improve communication and resolve disputes between farmers, DCOs and agencies. PMC meetings are chaired by a project manager appointed by the Irrigation Management Division. 


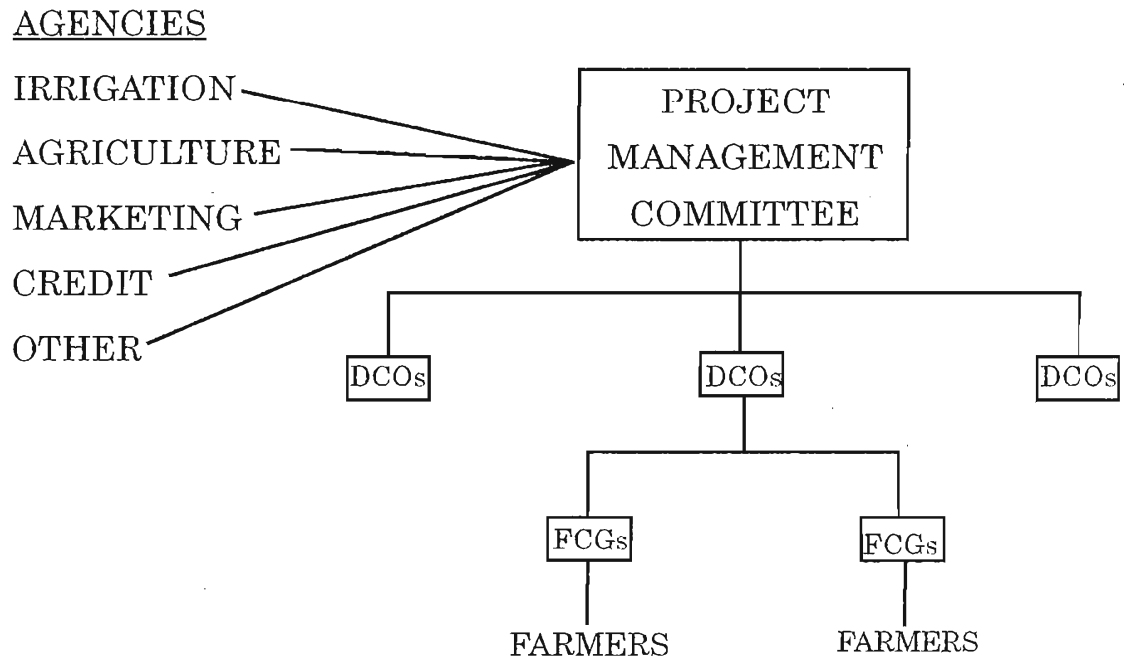

Figure 1: Organizational Structure adopted for the Participatory Irrigation Management at scheme level [Adopted from Aheeyar \& Smith (1998)]

Available information indicates that the main tangible impact of the introduction of participatory irrigation management has been an increase in the area cultivated, with little or no impact on crop productivity (Aheeyar 1996). The expansion in cultivated area is particularly evident for the Yala ${ }^{2}$ season in INMAS schemes, during the period 1984 to 1994. The area cultivated in the Yala season is determined by both the amount of rainfall received at the onset of the season and the amount of water left in the tank after the Maha season cultivation; i.e. on the efficiency of water use and degree of water saving efforts practised. Implementation of participatory irrigation management appears to have made increased Yala cultivation more possible than ever before through improvement in water distribution and efficiency of use. This paper reports the results of an investigation seeking to examine in more detail the impact of participatory management on water distribution performance. 


\section{Methodology}

Two schemes were selected for the study that were contrasting in terms of water scarcity and irrigated area, but otherwise representative of most irrigated agriculture in Sri Lanka. The degree of participation or net benefits from participation in water management, are likely to vary with water availability (Uphoff et al. 1990). Water availability largely determines cropping pattern, and hence farm income and farmers' capacity to mobilise resources for system maintenance. Organisational and physical complexity also vary with the size of the scheme and the condition of the infrastructure.

The schemes selected were Rajangana and Mee-oya irrigation schemes. Rajangana has a command area of about 6000 hectares and is located in North-Central province. The mean annual rainfall of the area is $1000-1500 \mathrm{~mm}$. Rainfall during the Yala is much less intensive, averaging $350-400 \mathrm{~mm}$ during the period of March and April. It has sufficient water to cultivate water-intensive crops (i.e. paddy) in the entire command area in the Maha season and most of the area in the Yala season. Mee-oya is smaller (1690 ha) and is located in the North-Western province. The area has typical dry zone characteristics. Dry period may prevail for 7-9 months in some of the years. It experiences relative water scarcity; requiring strict water management in the Maha season in order that the entire command area can be cultivated. Full cultivation is not possible in the Yala season.

According to the 96/97 Maha cultivation data, 83 and 17 percent of command area in Rajangana and 87 and six percent of the area in Mee-oya were under paddy and non-paddy crops respectively. In the 97 Yala season, areas under paddy and non- paddy crops in Rajanagana were 56 and 19 percent and in Mee-oya 22 and one percent respectively. Average paddy yield in Rajangana was 70-75 and 50-55 bushels per acre in Maha and Yala respectively, while the yields in Mee-oya for the same two seasons were 75-80 and 40-45 bushels per acre in Maha and Yala respectively. 
The tangible primary benefits resulting from effective participatory irrigation system management are expected to be, improved performance in water distribution in terms of adequacy, reliability, timeliness and equality between head, middle and tail end areas ${ }^{4}$. These were evaluated using the proxy indicators described below.

1. Process of water management:
a) the implementation of water schedules;
b) degree of water saving efforts by farmers;
c) share of water supply received by different field channels.

2. Farmer perceptions of adequacy, timeliness and reliability of water supply (as defined below), before and after introduction of participatory management .

3. Equality of water distribution between head and tail as revealed by :
a) variation in a water distribution index (WDI)
b) variation in the cost of weed control, or number of days weeds were controlled by storing irrigation water in the field ${ }^{5}$.

Supply of an adequate quantity of water, at the appropriate time and according to a planned schedule, is a primary objective of irrigation management and it is a major determinant of crop yield. Adequacy, timeliness and reliability of water issue are defined by Murray-Rust \& Snellen (1993) as follows:

Adequacy : The capacity of an irrigation system to meet the demands of farmers, and a measure of the ability of a water delivery to meet soil-plant water requirements. Adequacy objectives can be achieved by matching cropping plans and calendars with water availability and/or adjusting operational targets during the season. Adequacy therefore depends, not only on scheme water availability and main system management, but also irrigation and agronomic practices at farm level. 
Timeliness: Adequate delivery must match the time of crop water requirement, to avoid potential yield reductions caused by periods of water shortage.

Reliability: An expression of confidence in the irrigation system to deliver water as planned.

Farmer perceptions of adequacy, timeliness and reliability of supply were verified by using the above definitions. Each item was clearly defined to the farmers before gaining their response.

To assess equality of water distribution, a Water Distribution Index (WDI) was calculated using data from farm records maintained by sample ${ }^{6}$ farmers during the 1995/96 Maha season, in terms of water availability of each rotation (adequacy and timeliness). Volumetric measurement was not possible for this study due to the lack of necessary water measurement structures, hence the data is based on the farmer's perception of the amount of water received in each rotation, and the timeliness of supply as pre-planned given the crop requirements.

The WDI is the sum of two ratios as defined below:

$$
\begin{aligned}
& \text { WDI }=x_{2} / x_{1}+x_{3} / x_{1} \\
& x_{1}=\text { total number of rotations } \\
& x_{2}=\text { number of rotations with adequate supply of water } \\
& x_{3}=\text { number of rotations with timely supply of water }
\end{aligned}
$$

An Inter Quartile Ratio (IQR) calculation ${ }^{7}$ was used to assess the equality of water distribution. When the IQR values for the WDI are close to 1.0 there is no significant difference in water distribution between the head and tail parts of the system. 


\section{Results}

\section{Process of Water Management}

The water delivery pattern in Maha 1995/96 in the two schemes, as is most common in Sri Lanka, was continuous supply during land preparation for paddy and thereafter a rotational supply for the rest of the season. While this has been the usual pattern in the past, the important feature is that this is now planned and implemented by FOs. Previously it was done solely by the irrigation agency, although FOs had the opportunity to bargain for more supply when faced with water scarcity. Implementation of delivery schedules during the critical land preparation stage and degree of water saving efforts practised by farmers, were investigated to assess performance with participatory management.

\section{Implementation of Water Schedules}

Implementation of delivery schedules as planned is important to avoid wastage and to increase the efficiency of water use, particularly during the land preparation phase when water is issued continuously.

Table 1: Farmers' Perceptions of Implementation of Irrigation Schedule for Land Preparation (Percentage)

Rajangana

Mee-oya

Completion of Land Preparation

According to schedule 57 56

Delayed

Reasons for delay

Late supply of water

Unavailability of tractor

Lack of working capital

6

Source : Field Survey by the authors, 1996 
The survey of farmers revealed that just over fifty percent completed land preparation in accordance with planned water issues (Table 1). Late reception of water was the cause of delay for approximately twenty five percent of total farmers; non-availability of a tractor was the other major cause. The overall field survey data in table 1 implies that over seventy five percent of farmers receive their share of water on time to start land preparation.

\section{Water Saving by Farmers}

Respondents were asked whether all other farmèrs in their field channel made efforts to save water, in particular by reducing their off take of water as soon as their requirements were met. Data in Table 2 suggests that the majority of farmers attempt to save water in their fields, particularly in the. Mee-oya scheme where water scarcity is greater. Direct observation during field visits confirmed that most farmers try to save water by starting their cultivation with the onset of rainfall and reducing intake as soon as their fields have sufficient water.

Table 2: Farmers' Perception of Degree of Water Saving Efforts (percentage)

\begin{tabular}{lcccc}
\hline & $\begin{array}{c}\text { Rajangana } \\
\text { (Head) }\end{array}$ & $\begin{array}{c}\text { Rajangana } \\
\text { (Tail) }\end{array}$ & $\begin{array}{c}\text { Mee-oya } \\
\text { (Head) }\end{array}$ & $\begin{array}{c}\text { Mee-oya } \\
\text { (Tail) }\end{array}$ \\
\hline All farmers make efforts & 39 & - & 78 & 44 \\
Most farmers make efforts & 34 & 11 & - & 45 \\
Some farmers make efforts & 22 & 56 & 22 & 11 \\
No farmers make efforts & 5 & 33 & - & - \\
Number in sample & 18 & 18 & 9 & 9 \\
\hline
\end{tabular}

Source: Survey by the authors, 1996

\section{Share of Water Supply Received by Different Field Channels}

Farmer organization leaders from the head end of both systems reported that all field channels in their respective organisation's command area 
always received their due share of water from the current water allocation system. Similarly leaders from the tail end of Rajangana reported that most of their field channels normally received their due supply. Leaders from the tail end of Mee-oya revealed that some field channels only received their due supply for some of the time; reflecting the greater water scarcity in this scheme.

\section{Adequacy, Timeliness and Reliability of Supply}

Table 3 indicates that almost one hundred percent of Rajangana farmers perceive that their water supply is adequate, supplied at appropriate times and with satisfactory reliability. In comparison these indicators of performance are considerably poorer for Meeoya.

Table 3: Farmer Perceptions of Quality of Irrigation Service. Percentage of Farmer Responses ( all farmers)

\begin{tabular}{lcc}
\hline & Rajangana & Mee-oya \\
\hline Adequacy & 97 & 72 \\
Timeliness & 91 & 61 \\
Reliability & 97 & 61 \\
\hline
\end{tabular}

Source : Survey by the authors, 1996

According to key informants, the differences between the schemes are attributable to water scarcity and the poor condition of the canal system in Mee-oya. Rajangana scheme had been rehabilitated prior to turnover to participatory management, but not Mee-oya. Water scarcity is particularly acute at Mee-oya in the later part of the season (crop maturity phase) compared to the land preparation and crop growth phases. This was also reflected in farmers' perceptions for these three indicators. 


\section{Equality of Water Distribution}

Water Distribution Index (WDI)

Table 4 shows the results obtained for the WDI at six locations. Values for the WDI can vary from $0-2$, and were used to calculate the Inter Quartile Ratio (IQR) values. The IQR for Rajangana was 1.01 and for Mee-oya 2.9. These values confirm that water distribution in Rajangana is equal, with no significant differences in supply to head and tail reaches. For Mee-oya, analyzed data show the existence of significant variations in adequacy and timeliness of water supply within the system. The greater equality in terms of adequacy and timeliness of water supply between head and tail of Rajangana has been achieved by strict and uniform adoption of scheduled water rotations, regardless of head and tail locations.

Table 4: Water Distribution Index (WDI) Values for Different Locations

\begin{tabular}{ccccccc}
\hline Sample & Location & Location & Location & Location & Location & Location \\
\hline 1 & 2.0 & 2.0 & 1.85 & 2.0 & 2.0 & 2.0 \\
2 & 2.0 & 2.0 & 2.0 & 2.0 & 2.0 & 2.0 \\
3 & 2.0 & 2.0 & 2.0 & 2.0 & 2.0 & 1.66 \\
4 & 2.0 & 2.0 & 1.9 & 2.0 & 2.0 & 1.33 \\
5 & 2.0 & 2.0 & 2.0 & 2.0 & 2.0 & 1.42 \\
6 & 2.0 & 2.0 & 2.0 & 2.0 & 2.0 & 1.49 \\
7 & 2.0 & 2.0 & 2.0 & 1.85 & 2.0 & 2.0 \\
8 & 2.0 & 2.0 & 2.0 & 2.0 & 2.0 & 0.75 \\
9 & 2.0 & 2.0 & 2.0 & 2.0 & 2.0 & 1.16 \\
\hline
\end{tabular}

Key: Location 1 and 2 - Head end of Rajangana

Location 3 and 4 - Tail end of Rajangana

Location 5 - Head end of Mee-oya

Lucation 6 - Tail end of Mee-oya

Source: Field Survey by the authors, 1996 


\section{Cost of Weed Control}

Table 5 summarizes the results obtained from analysis of weed control data. This includes number of days of weed control by storing water in the field, and cost involved in weed control (chemicals and labour) in the Maha 1995/96 season.

For these two variables the difference between head and tail reaches is considerably more for Mee-oya than for Rajangana although water availability is much higher in the latter scheme. This again suggests greater equality of water distribution in Rajangana compared to Mee-oya. Lower cost of weed control in Mee-oya is the result of less use of herbicides. Farmers in Mee-Oya prefer to use manual and mechanical methods of weed control which cost less. They are reluctant to invest in agro-chemicals because of the higher risk associated with lower quality irrigation supply in terms of adequacy, timeliness and reliability. According to key informants farmers in Rajangania are not able to use water as a method of weed control, because water is allocated on a strict rotational basis.

Table 5: Spatial Differences in Cost of Weed Control

\begin{tabular}{lcc}
\hline & $\begin{array}{c}\text { Average No. of days } \\
\text { of weed control by } \\
\text { storing water }\end{array}$ & $\begin{array}{c}\text { Average cost involved } \\
\text { in weed control } \\
\text { (Rs. per acre) }\end{array}$ \\
\hline Rajangana (Head) & 10.8 & 977.00 \\
Rajangana (Tail) & 8.3 & 1099.00 \\
Mee-oya (Head) & 16.6 & 243.00 \\
Mee-oya (Tail) & 5.0 & 533.00 \\
\hline
\end{tabular}

Source : Field Survey by the authors, 1996 


\section{Conclusion}

It is difficult to quantify and attribute the change in performance occurring with participatory management, but farmer responses do suggest that schedules prepared by FOs are better planned and more effectively implemented than was the case under agency management. The two schemes are not atypical and if water has generally been used inefficiently in the past, particularly by head end farmers (e.g. Moore 1981; Chambers 1988), then evidence of efforts to save water by the majority of farmers indicates improvement in water distribution; similarly, reports that most field channels received a fair share of water supply regardless of location. In addition, farmers suggest that there is now more flexibility in terms of ability to respond to the needs of individual farmers, reflecting a greater understanding of, and sympathy with, farmer requirements by both the line agency and FO. This is important in securing the participation of all farmers in irrigation management.

According to irrigation officials, conflicts over water and the breaking of control structures by farmers were also common problems in the past. In these schemes officials reported that with increased farmer participation in irrigation management, the incidence of water related conflicts and purposive damage to structures by farmers had decreased by the order of ninetyfive percent. This also indicates improvement in the quality of water distribution.

Performance of irrigation in terms of efficiency and equality of water distribution is extremely difficult to assess (Smith 1990). Though hampered by the lack of baseline, i.e. pre-management turnover data, for comparison, this study has assessed the impacts of farmer participation on irrigation water distribution performance using farmer perceptions of irrigation service quality and other proxy indicators. The adequacy, timeliness and reliability of water supply, and the equality in water distribution between head and tail reaches, have improved in both schemes studied. 
The improved performance in water distribution with farmer participation has been observed by many researchers (Abeywickrama, 1998; Perera and Jinapala, 1998). An island-wide study conducted by IIMI/ HARTI (1997) in 200 irrigation schemes also reveals that the major benefit identified by farmers in participatory management is improved water distribution performance due to various reasons.

This improvement is the result of a combination of many factors. Decentralization of water management responsibilities to field channel level and appointment of farmer representatives in management, has increased the efficiency of water management tasks and responsiveness to farmers' needs. Water conflicts have been reduced following improved supply in terms of adequacy, timeliness and reliability, and improved communication, trust and mutual understanding between farmers and officials. There has been a reduction in the use of water for weed control, particularly by head-enders.

The availability of water has also increased due to improved maintenance performance and increased operation performance of irrigation systems compared to the past. Although irrigation distribution performance and on-farm water management shows an improvement under the PISMP, Aheeyar (1999) argues that the level of resource mobilization in terms of cash and materials for system maintenance by both FOs and the line agency is not yet sufficient for the sustainable maintenance of irrigation canals. The existing situation in resource mobilization could lead to deterioration of canals in the long run and wastage of water above the field channel level.

\section{Notes}

1 The success of an irrigation project depends largely on the active participation and co-operation of individual farmers. Irrigation technician cannot satisfactorily operate and maintain the system (ODU Bulletin, 31:1995,p.7). 
2 Yala is the "dry" season which receives south-east monsoonal rain. Rainfall mainly prevails during March to June. The dry zone of Sri Lanka receives little rain during this season.

3 Maha is the wet and major cultivation season in Sri Lanka; extending from October to January, it receives monsoonal rain from the north-east monsoonal wind.

4. Variation in water supply is not confined to main canals. Uphoff (1990) observed differences between head and tail reaches within distributory canals and field channels. A farm at the head of field channel located at the tail of a main canal, may have better supply than a farm at the tail of a field channel at the head of the main canal.

5 Since the economic cost of water to all farmers is very low, and constant, regardless of amount used, irrigation water may be used to control weeds in rice fields, especially by head end farmers. Use of water to retard weed growth has been common, harming tail end farmers by leading to inequality in water distribution.

6 Thirty six farmers from Rajangana and 18 from Mee-oya were randomly selected, using a stratified multi-stage selection procedure.

7 The IQR compares the average of the top 25\% of values (Abernethy 1986).

\section{References}

Abernethy C.L. (1986). Performance Measurement in Canal Water Management. ODI/IIMI Irrigation Management Network Paper 86/2d, London: ODI.

Abeywickrama L.M. (1998). "Role of Farmer Organizations in Canal Irrigation Systems: A Case Study in Uda Walawe Irrigation and Settlement Scheme" Paper presented at the National Conference on Status and Future Direction of Water Research in Sri Lanka, BMICH, Colombo, 4-6, November. (mimeo). 
Aheeyar M.M.M. (1996). Participatory Irrigation System Management in Sri Lanka: Experiences and Prospects. M.Phil. Thesis, Wye College, University of London.

Aheeyar M.M.M \& Smith L.E.D. (1998). Participatory Irrigation Management in Sri Lanka: Lessons of Experience. ICID Journal Vol 47: 02, 77-86

Aheeyar M.M.M. (1999). Impact of Irrigation Management Policy on Environment: Lessons from Sri Lanka. Asia Pacific Journal of Rural Development Vol ix, No: 01, 71-78

Aluwihare P.B. \& Kikuchi M. (1990). Irrigation Investment Trends in Sri Lanka: New Construction and Beyond. Colombo: International Irrigation Management Institute.

Alwis J. (1986). "An Analysis of Trends and Perspectives in Policies for Irrigation Water Management and Agricultural Development in Sri Lanka". Paper presented at the Seminar on Irrigation Water Management and Agricultural Development of Sri Lanka, Agrarian Research and Training Institute, Colombo, Sri Lanka, 20-21; February (mimeo).

Barker R. \& Herdt R.W. (1985). The Rice Economy of Asia. Washington, D.C.: Resources for the Future.

Brohier R.L. (1934). Ancient Irrigation Works in Ceylon. Colombo: Ceylon Government Press.

Carruthers, I.D. \& Morrison J. (1994). "Irrigation Maintenance Strategies: A Review of the Issues", A Report Submitted to the Deutsche Gesellschaft Fur Technischue Zusammenarbeit (GTZ) GMBH, Ministry of Economic Cooperation and Development (BMZ), Germany.

Chambers R. (1988). Managing Canal Irrigation: Practical Analysis from South Asia. Oxford: Oxford University Press.

IIMI/HARTI (1997). Monitoring and Evaluation of Participatory Irrigation. System Management Policy. Colombo: International 
Irrigation Management Institute and Hector Kobbekaduwa Agrarian Research and Training Institute.

IMPSA (1991). Institutional Framework for Management of Irrigation Systems and Building Farmers' Organisations. Policy Paper No. 2, Irrigation Management Policy Support Activity, Colombo.

Moore M.P. (1981). The Sociology of Irrigation Water Management in Sri Lanka. Water Supply and Management 15:1, 117-133.

Murray-Rust D.H. \& Snellen W.B. (1993). Irrigation System Performance Assessment and Diagnosis. Colombo: International Irrigation Management Institute.

Perera, L.R. \& Jinapala K. (1998). “A Community Management Model Tested For Irrigation Management Transfer in Moraketiya D7 of Embilipitiya Block of Uda Walawe Project", Paper presented at the National Conference on Status and Future Direction of Water Research in Sri Lanka, BMICH, Colombo, 4-6, November. (mimeo).

Seneviratne A. (1989). The Springs of Sinhala Civilization. New Delhi: Navarang.

Silva M. (1986). The Evolution of Policies in Sri Lanka Relating to the Covering of Water Charges From Farmers for Irrigation Services. Colombo: International Irrigation Management Institute.

Smith L.E.D. (1990). An Economist's Perspective on Irrigation Performance Assessment: With Examples from Large Scale Irrigation in Morocco. Irrigation and Drainage Systems 4:3, 329-343.

Uphoff N., Wickramasinghe M.L. \& Wijayarathna C.M. (1990). Optimum Participation in Irrigation Management: Issues and Evidence from Sri Lanka. Human Organisation 49:1, 26-40.

Wickramasekara P. (1981). Water Management Under Channel Irrigation: A Study of the Minipe Settlement in Sri Lanka. Department of Economics, University of Peradeniya, Sri Lanka. 